\title{
PENGATURAN CORPORATION SOCIAL RESPONSIBILITY SEBAGAI PENDAPATAN DESA ADAT DI BALI
}

\author{
I Gusti Agung Gde Dharmada, Balipost, e-mail: \\ gungdharmada@gmail.com \\ Dewa Nyoman Rai Asmara Putra'Fakultas Hukum Universitas Udayana, e-mail: \\ dewar2566@gmail.com
}

doi: https://doi.org/10.24843/KS.2020.v08.i12.p11

\begin{abstract}
ABSTRAK
Pemerintahan adat bersifat keagamaan dan budaya yang membutuhkan pembiayaan yang bersifat terus menerus dan tidak sedikit. Perkembangan investasi dunia usaha di wewidangan desa adat sangat pesat. Sektor industri atau korporasi skala besar mulai masuk ke pelosok - pelosok desa dan mampu memberikan kontribusi terhadap pertumbuhan ekonomi nasional. Eksploitasi oleh industri berdampak terjadinya degradasi lingkungan. Dalam mempertanggungjawabkan dampak - dampak sosial, ekonomi dan lingkungan diperlukan tanggung jawab sosial dari korporasi berupa pemberian CSR (Corporation Social Responsibility). Untuk itu penulisan bertujuan menganalisa dan mengetahui berkaitan penormaan pungutan CSR perusahaan agar dapat dimanfaatkan sebagai sumber pendapatan sah bagi desa adat di Bali. Penelitian dilakukan secara normatif dengan menggunakan pendekatan perundang - udangan (Statue Approach) yang beranjak dari adanya kekosongan norma. Sejak Putusan MK No 53/PUUVI/2008, CSR menjadi paradok dalam kontek filantropi. Bagi desa adat di dalam merubah paradigma CSR yang bersifat voluntary dan Filantropi menjadi sebuah kewajiban hukum hendaknya disikapi melalui pengaturan hukum, dalam bentuk kesepakatan yang kemudian diatur dalam bentuk awig-awig, pararem dan jenis peraturan adat lainnya.
\end{abstract}

Kata kunci: desa adat, voulantary, filantropi, awig-awig, peraturan

\begin{abstract}
Tradition government is religious and cultural in nature, which requires ongoing funding and is not that a little. The development of business investment in the authority of indigenous villages is very rapid. Large-scale industrial or corporate sectors began to enter remote villages and were able to contribute to national economic growth. Exploitation by industry impacted on the environmental degradation. In taking responsibility for the impacts to social, economic and environmental, social responsibility from corporations is needed in the form of CSR (Corporation Social Responsibility). For this purpose, the aim is to analyze and see indicators of normalizing company CSR levies so that they can be used as a source of income for traditional villages in Bali. The study was conducted normatively using Statue Approach that moved from the absence of norms. Since the Constitutional Court Decision MK No. 53 / PUU-VI / 2008, CSR has become a paradox in the context of philanthropy. For traditional villages in changing the CSR paradigm which is voluntary and philanthropic into a legal obligation should be addressed through legal arrangements, in the form of agreements which are then regulated in the form of awig-awig, pararem and other types of custom regulations.
\end{abstract}

Keywords: custom village, voluntary, philanthropy, awig-awig, regulation 


\section{PENDAHULUAN}

\subsection{Latar Belakang Masalah}

Dunia usaha dalam perkembangan globalisasi mempunyai tanggung jawab dalam membuat keuntungan bagi pemodalnya. Memperoleh profit oriented merupakan tujuan dari sebuah perseroan. Dalam mengembangkan suatu perseroan tidak dapat dipisahkan dengan lingkungan dan masyarakat sekitarnya. Tanpa dukungan masyarakat, mustahil suatu perusahan memiliki pelanggan, pegawai dan sumber sumber produksi lainnya. Semua itu diperlukan dalam rangka semua aktvitas perusahaan berjalan dengan seimbang.

Meskipun perusahaan telah membayar pajak kepada Negara bukan berarti telah menghilangkan tanggung jawabnya terhadap kesejahteraan publik. Oleh karena itu perusahaan haruslah mengadopsi kenyataan bahwa ada dua bentuk perjanjian yang harus dipatuhi agar dapat beroperasi dengan aman, diantaranya, yaitu ijin legal dari pemerintah dan ijin sosial dari masyarakat dengan melakukan kegiatan sosial atau Corporation Social Responsibility (CSR). CSR sangat relevan diterapkan oleh dunia usaha. Karena kebijakan sosial dan kebijakan kesejahteraan cendrung bernuansa risedual atau parsial, tidak melembaga dan terintegrasi dengan sistem perpajakan seperti halnya di Negara - Negara yang menganut Welfare State, mayoritas masyarakat masih dalam kondisi serba kekurangan.

Di Indonesia konsep CSR menguat setelah keluarnya UU Nomor 40 Tahun 2007 tentang Perseroan Terbatas (UUPT). Pasal 1 angka 3 menguraikan bahwa Tanggung jawab sosial dan lingkungan (TJSL) merupakan komitmen perseroan dalam berperan serta dalam pembangunan ekonomi berkelanjutan guna meningkatkan kualitas kehidupan dan lingkungan yang bermanfaat, baik bagi perseroan sendiri, komunitas setempat, maupun masyarakat pada umumnya. Perumusan program CSR ke dalam peraturan perundang - undangan sebagai akibat perseroan hanya melakukan kegiatan operasionalnya namun kurang memberikan perhatian terhadap masyarakat sekitarnya. Kondisi ini secara khusus masih terlihat dalam interaksi perseroan dengan desa adat di Bali. Desa Adat merupakan organisasi komunal masyarakat Bali yang mempunyai batas wilayah, penduduk, hukum adat serta tata krama dalam satuan tradisi pergaulan hidup masyarakatnya (self Governing community). ${ }^{1}$

Eksistensi desa adat sebagaimana amanat konstitusi pasal 18B UUD 1945, yang kemudian di Provinsi Bali dibuatkan payung hukum dalam bentuk Perda Nomor 4 tahun 2019 tentang Desa Adat di Bali. Perda ini merupakan perubahan dari Perda Bali Nomor 3 Tahun 2001 tentang Desa Pakraman. Kata Pakraman sejak tanggal 4 Juni 2019 tidak lagi digunakan dalam penyebutan desa adat di Bali. Dan, sejak diberlakukannya regulasi pemerintah daerah provinsi Bali tersebut sebanyak 1.493 deda adat di Bali merupakan subjek hukum. Artinya, desa adat sebagai pembawa hak yang mempunyai hak dan kewajiban untuk bertindak dalam hukum.

Mengacu pada definisi tentang desa adat sebagaimana ketentuan Pasal 1 angka (8), memberikan ruang tersendiri bagi desa adat untuk mengatur dan mengurus rumah tangganya sendiri. Tata krama pergaulan masyarakat secara turun - temurun dilakukan dalam ikatan pura kahyangan tiga. Kehidupan sosial dan religius masyarakat adat ini terus berkembang, secara turun temurun. Interaksi kehidupan masyarakat adat Bali yang unik, disertai keindahan alamnya menjadi daya tarik masyarakat dunia, memilih Bali sebagai tempat kunjungan wisata.

${ }^{1}$ Adharinalti, A. "Eksistensi Hukum Adat Dalam Penyelenggaraan Pemerintahan Desa Di Bali." Jurnal Rechts Vinding: Media Pembinaan Hukum Nasional, 1(3), (2012): 2. 
Dalam menjalankan pemerintahan adat yang bersifat keagamaan, adat dan budaya, dibutuhkan biaya yang tidak sedikit. Pelestarian kebudayaan dan adat istiadat memerlukan biaya yang bersifat terus menerus. Desa adat yang memiliki sumber daya alam yang cukup dapat memanfaatkan sebagai sumber pendapatan. ${ }^{2}$ Pendapatan desa adat dapat berasal dari hibah dan sumbangan (dana punia) sebagaimana diatur dalam Pasal 65 ayat (1) Perda Desa Adat di Bali. Pendapatan hibah dan sumbangan pihak ketiga ini dapat bersumber dari CSR perusahaan - perusahaan yang ada di wewidangan desa adat. Mulai dari usaha industri, usaha jasa pariwisata, usaha perdagangan, otomotif, dan sebagainya.

CSR secara normatif merupakan kewajiban moral bagi perusahaan atau korporasi yang berdiri di tengah masyarakat. Namun, arah pemanfaatan CSR masih parsial dan belum di atur secara jelas oleh pemerintah. Masih terjadi kekosongan hukum terhadap pemanfaatan CSR sebagai suatu sumber pendapatan desa adat di Bali.

Pemerintah Daerah Provinsi Bali memiliki program pemberdayaan desa adat, CSR masih menjadi paradok dalam kontek filantropi, guna memberdayakan desa adat di Bali. Besarnya biaya dalam upaya melestarikan nilai kebudayaan dan tradisi yang dilakukan desa adat, sekiranya dapat dibuatkan sebuah regulasi sehingga bisa dimanfaatkan sebagai pendapatan bagi desa adat. Kepastian hukum atas perbuatan hukum pemberian CSR suatu perusahaan kepada desa adat di Bali sangat diperlukan, guna menghindari kesan adanya pungutan liar.

\subsection{Rumusan Masalah}

Berdasarkan uraian diatas, dapat ditarik rumusan masalah sebagai berikut:

1. Apakah CSR dapat dimanfaatkan sebagai sumber pendapatan dari Desa Adat di Bali?

2. Bagaimanakah pengaturan CSR dalam kaitannya sebagai sumber pendapatan desa adat di Bali?

\subsection{Tujuan Penulisan}

Penulisan ini bertujuan untuk menganalisa dan mengetahui berkaitan dengan penormaan pungutan CSR perusahaan untuk dapat dimanfaatkan sebagai sumber pendapatan yang sah bagi desa adat di Bali dalam kaitannya mewujudkan kesejahteraan masyarakat adat.

\section{METODE PENELITIAN}

Penelitian ini dilakukan secara normatif dengan menggunakan pendekatan perundang - udangan (Statue Approach) dengan memahami hirarki dan asas - asas dalam peraturan - udangan. Selain itu, juga digunakan pendekatan konseptual guna menguraikan dan menganalisa permasalahan yang beranjak dari adanya norma kosong 3 . Bahan hukum yang digunakan dari bahan hukum primer dan bahan hukum sekunder untuk meneliti peraturan perundang - udangan dan buku terkait. Untuk

2 Yudiawan, I. D. H. "Pendapatan desa adat: Kontruksi hukum pungutan untuk Mewujudkan Bebas pungutan Liar." Jurnal magister hukum Udayana (Udayana Master Law Journal), 8(2),_Https:/ / Doi.Org/10.24843/Jmhu.2019.V08.I02.P08. (2019): 251.

3 Pasek Diantha I Made. "Metodelogi Penelitian Hukum Normatif." Jakarta: Prenada Media Group, (2017): 159. 
menjelaskan dan memberikan petunjuk atas bahan hukum primer dan bahan hukum sekunder maka digunakan juga bahan hukum tersier. Sumber hukum tersebut kemudian dikumpulkan dengan teknik bola salju dan dianalisa dengan menggunakan teknis argumentatif.

\section{HASIL DAN PEMBAHASAN}

3.1. Pemanfaatan CSR Sebagai Sumber Pendapatan Desa Adat

CSR atau Corporate Social Responsibility merupakan suatu konsep yang mengandung arti bahwa organisasi atau lembaga perusahaan bukan lagi sebagai entitas yang hanya mementingkan dirinya sendiri, melainkan sebuah usaha yang wajib melakukan adaptasi kultural dengan lingkungan sosialnya. Semua kegiatan yang dilakukan oleh suatu perusahaan dapat dipastikan memberikan dampak eksternal yang harus ditanggung oleh perusahaan itu sendiri. Sehingga wajar bilamana perusahaan/lembaga memperhatikan kepentingan dari kelompok masyarakat maupun lingkungan sekitar.

Program CSR di Indonesia dapat ditemui dalam beberapa peraturan perundang - undangan. Peraturan tentang CSR bukan hal baru bagi korporasi. Di negera maju setiap korporasi diwajibkan untuk melaporkan secara periodik pelaksanaan CSR-nya. Hal ini untuk melakukan pengawasan dan kontrol bagi perusahaan yang tidak menjalankan program CSR. Sanksi yang diberikan bagi perusahaan yang melanggar juga diberikan mulai dari sanksi yang ringan seperti peringatan tertulis hingga peninjauan kembali soal perizinanannya.

Regulasi mengenai CSR dibentuk mencapai kesepakatan niat baik dalam pembangunan lingkungan. Aturan tersebut dibuat secara mengikat agar tidak ada pengecualian dalam pelaksanaannya. Dari penelusuran penulis, sedikitnya ada enam regulasi yang mengatur prihal program CSR. Regulasi tersebut sebenarnya sudah di mulai sejak tahun 1994. Melalui Kemenkeu RI No. 316/KMK.016/1994, diintruksikan bagi BUMN untuk turut serta dalam meningkatkan kesejahteraan masyarakat dan lingkungan sekitar melalui program kemitraan dan bina lingkungan.

Pemenuhan CSR juga dibuat secara khusus bagi perusahaan di bidang minyak dan gas, termuat dalam UU No. 22 tahun 2001. Pasal 11 ayat (3) huruf P dimana dalam melakukan kontrak kerjasama, kegiatan usaha wajib melakukan pengembangan masyarakat sekitarnya dan jaminan hak - hak masyarakat adat.

Kewajiban melaksanakan CSR juga diatur dalam peraturan yang membahas masalah SDA, yaitu UU Nomor 40 Tahun 2007 (UUPT). Pasal 74 mengatur berkenaan bahwa usaha yang bergerak di bidang sumber daya alam wajib melaksanakan tanggung jawab sosial dan lingkungan (TJSL). TJSL merupakan kewajiban perusahaan, yang apabila dilanggar dikenakan sanksi sesuai peraturan perundang - udangan. Pelaksanaan UUPT lebih lanjut di atur dalam PP Nomor 47 Tahun 2012 tentang Tanggungjawab sosial dan lingkungan perseroan terbatas.

Program CSR juga dapat ditemui dalam UU Nomor 25 Tahun 2007 (UUPM). Dalam ketentuan tersebut dengan tegas disebutkan bahwa setiap PT atau penanaman modal mempunyai kewajiban melakukan tanggung jawab sosial perusahaan dengan penganggaran yang telah di tentukan oleh UU. Dalam peraturan ini juga disertai dengan sanksi apabila pelaku usaha tidak menjalankan kewajibannya dalam program CSR. Pasal 34 mengatur sanksi dapat berupa administratif juga sanksi lainnya, seperti peringatan tertulis, pembatasan kegiatan usaha, peningkatan tertulis, pembatasan kegiatan usaha, pembekuan kegiatan usaha hingga pencabutan kegiatan usaha. 
Dalam penjelasan pasal 36 ayat (1) UU Nomor 13 Tahun 2011 terkait penanganan masyarakat dengan perekonomian rendah juga menyebutkan program CSR. Sumber pendanaan dalam penanganan fakir miskin meliputi uang yang disisihkan dari perusahan perseroan. Selain itu, pelaku usaha juga diharapkan untuk berperan dalam menyediakan uang pengembangan masyarakat sebagai perwujudan dari tanggung jawab sosial terhadap penanganan fakir miskin.

Terhadap pengaturan dalam perundang - undangan harus mampu mengakomodir kepentingan semua pihak. Pelaku usaha yang orientasinya hanya keuntungan, tentunya tidak setuju apabila regulasi yang ada mengganggu kepentingan mereka. Masyarakat atau lingkungan di sekitar perusahaan tersebut yang menerima dampak kehadiran korporasi menuntut kontribusi bagi mereka. Sehingga peraturan yang dibuat agar mengakomodasi semua stakheholder. Pengaturan hukum terhadap kewajiban perusahaan untuk melakukan CSR tidak berjalan mulus. Beragam respon dilakukan oleh kalangan dunia bisnis, ada yang mendukung dan ada menolak. Penolakan pengaturan CSR sebagai sebuah mandatory, bahkan dilakukan dengan pengajuan permohonan uji materiil terhadap Pasal 74 UU PT ke MK. Putusan MK No. 53/PUU-VI/2008, menegaskan pergeseran paradigma CSR dari sukarela menjadi kewajiban hukum.

Kewajiban perusahaan dalam pemberian CSR tidak semata - mata hanya mematuhi peraturan perundang - undangan sebagaimana diuraikan diatas. Akan tetapi juga merupakan sebuah kewajiban moral. Hal ini sejalan dengan teori legitimasi, dimana sebuah legitimasi masyarakat menjadi faktor strategis bagi perkembangan sebuah perusahaan ke depan. Dalam menentukan sumber keuangan dan ekonomi, cenderung menggunakan kinerja berbasis lingkungan dan informasi lingkungan untuk melegitimasi aktivitas perusahaan di mata masyarakat.

CSR sebuah perusahaan erat kaitannya dengan budaya dan spiritual masyarakat di lingkungan perusahaan itu berada. Hal ini sejalan dengan kebudayaan masyarakat Indonesia yang religius, dimana memiliki keyakinan dan kepercayaan bahwa Tuhan Yang Maha Esa sebagai pencipta alam semesta. ${ }^{4}$ Penerapan program CSR di Indonesia berdasarkan atas paradigma yang berbeda. Mulai dari dorongan amal berdasarkan motivasi keagamaan (corporate charity), dorongan kemanusiaan (corporate philanthropy), dan motivasi kewargaan keadilan sosial (corporate citizenship). Dari segi pelaksanaannya, pola CSR yang umumnya diterapkan adalah dengan melakukan keterlibatan langsung, melalui yayasan atau organisasi sosial, bermitra dengan pihak lain dan mendukung atau bergabung dalam suatu konsorsium ${ }^{5}$.

Penerapan CSR tergantung pada kesadaran dan komitmen perusahaan. Kesadaran dan komitmen tidak serupa, dan tergantung pada kebijakan perusahaan. Hal ini menjadi kelemahan yang mendasar dalam penerapan program CSR. Begitu besarnya manfaat yang diperoleh apabila CSR dilaksanakan dengan aturan dan arahan yang jelas, di sisi lain ketidak taatnya perusahaan dalam mengimplementasikan program CSR tidak disertai sanksi tegas bagi perusahaan yang melanggarnya.

CSR secara konsep bersifat voluntary dan Filantropi. Secara etimologis, Filantropi bermakna kedarmawanan. Praktek kedarmawanan sudah dikenal jauh sebelum

4 Pertiwi, I. D. A. E., \& Ludigdo, U. “Implementasi Corporate Social Responsibility Berlandaskan Budaya Tri Hita Karana." Jurnal Akuntansi Multiparadigma, 4(3), (2013): 430-455.

5 Tanudjaja, B. B. "Perkembangan Corporate Social Responsibility Di Indonesia." Nirmana, 8(2), 92-98. Https://Doi.Org/10.9744/Nirmana.8.2.Pp.\%2092-98, (2009): 96. 
adanya istilah CSR. Kedermawanan menjadi bagian kehidupan masyarakat nusantara sejak ratusan tahun lalu. Praktek ini sebagai bagian tradisi masyarakat di berbagai suku yang tersebar di nusantara. Di samping itu juga menjadi bagian dari ajaran kegiatan keagamaan yang tumbuh di Indonesia.

Di Bali, praktek filantropi menjadi bagian dari ajaran keagamaan masyarakatnya. Dalam masyarakat adat Bali yang berlandaskan ajaran agama Hindu, filantropi dilakukan melalui madana punia. Dana punia atau hibah dan sumbangan pihak ketiga yang tidak mengikat merupakan salah satu sumber pendapatan desa adat sebagaimana diatur dalam Pasal 65 ayat (1) huruf f, Perda Desa Adat di Bali. Dimana sumber pendapatan tersebut dapat digunakan untuk membiayai penyelenggaraan program desa adat.

Kegiatan filantropi yang berkaitan dengan ajaran keagamaan bersifat wajib dan sebagian lainnya bersifat sukarela (voluntary), dalam rangka tolong menolong, kerjasama, hubungan antarmanusia. Bentuk filantropi ada dua, yaitu filantropi tradisional dan filantropi untuk keadilan sosial. Keduanya masing-masing mempunyai kelebihan dan kelemahan. Filantropi tradisional berbasis karitas, berbentuk pemberian untuk pelayanan sosial. Sebagai contoh, pemberian para darmawan secara langsung kepada kalangan kurang mampu dalam memenuhi kebutuhan sehari-hari. Kelemahannya adalah tidak bisa mengembangkan taraf kehidupan masyarakat tersebut. Bentuk Filantropi untuk keadilan sosial dapat menjembatani antara pemisah antara yang kaya dengan yang miskin. Penghubungnya di sini dilakukan dengan mendukung kegiatan dengan mencari akar dari sumber penyebab kemiskinan itu, baik karena alokasi sumber daya, dana atau akses kekuasaan dalam masyarakat.

\subsection{Pengaturan CSR Sebagai Sumber Pendapatan Desa Adat di Bali}

Kehadiran dunia usaha ke ranah palemahan desa adat, dengan mengembangkan berbagai bidang usaha, bertujuan untuk tumbuh dan berkembang yang berorientasi pada keuntungan. Dari tujuan utama tersebut, dunia usaha tidak terlepas dari kondisi lingkungannya. Perseroan harus memperhatikan masyarakat dan lingkungan sekitarnya, agar semua aktivitas berjalan seimbang. Dalam dunia usaha muncul berbagai diskursus berkaitan dengan pengelolaannya. Tidak semua perusahaan menerapkan program CSR perusahaan kepada lingkungan sekitarnya sebagaimana diamanatkan oleh peraturan perundangan.

Perseroan merupakan pendukung hak dan kewajiban yang lazim dikenal sebagai subjek hukum. Yang termasuk dalam subjek hukum adalah manusia dan badan hukum 6 . Secara yuridis, badan hukum mempunyai wujud riil mempunyai kesamaan dengan manusia. Idealnya badan hukum juga berlaku seperti manusia. Manusia dalam kenyataannya adalah sebagai mahkluk sosial, yang dipengaruhi oleh banyak aspek - aspek di luar diri manusia itu sendiri untuk menciptakan kehidupan yang harmonis dan nyaman.

Badan hukum dalam menjalankan usahanya dilihat dari perspektif kenyataan sosial domisilinya, keberadaannya harus diimbangi juga dengan pertanggungjawaban terhadap lingkungan sosialnya. CSR merupakan salah satu wujud kepedulian dunia usaha kepada masyarakat sekitar melalui berbagai bentuk program peduli. CSR

6 Tanaya, P. E. “Tinjauan Sosiologi Hukum Terhadap Corporate Social Responbility (Csr) Sebagai Etika Bisnis Dan Etika Sosial." Jurnal Komunikasi Hukum (Jkh), 2(2). Http:/ / Dx.Doi.Org/10.23887/Jkh.V2i2.8417, (2016): 270 
dikembangkan melalui tiga prinsip mendasar yang mencakup; sosial, ekonomi, dan lingkungan. Dimana ketiga prinsip tersebut dalam pelaksanaannya dikaitkan dengan masalah etis, moral dan kepatutan?.

Pelaksanaan CSR sebenarnya ada hubungan timbal balik yang saling membutuhkan dan saling mempengaruhi antara perusahaan dengan desa adat. Desa adat terdiri atas individu-individu yang tergabung dalam masyarakat adat setempat. Masyarakat adat yang berada di sekitar perusahaan adalah pemangku kepentingan utama dari sistem perusahan. Ini tidak terlepas dari hakikat masyarakat memberikan dukungan atas keberlangsungan operasional perusahaan. Desa adat sebagai pihak pemangku kepentingan utama, maka masyarakat yang ada dalam desa adat itu harus dianggap sebagai bagian dari perusahaan.

Adaptasi kultural dengan lingkungan sosialnya dapat memberikan dampak eksternal bagi perusahaan itu sendiri. Untuk itu wajar bila perusahaan atau lembaga memperhatikan kepentingan dari kelompok masyarakat maupun lingkungan sekitarnya dalam hal ini desa adat yang mempunyai hak otonom dalam mengatur pemerintahannya sendiri.

Desa adat di Bali sejak lahir telah memiliki prinsip otonomi. Prinsip ini disertai dengan hak otonom. Prinsip otonom desa adat berbeda dengan prinsip otonomi pada hukum Negara. Konsep otonomi yang dimiliki oleh desa adat mempunyai landasan yang kuat bersumber dari hak kondrati yang dimiliki oleh desa adat itu sendiri. Desa Adat di Bali mempunyai 3 kekuasaan untuk mengatur rumah tangga sediri. Diantaranya menetapkan aturan hukum, menyelenggarakan kehidupan organisasi, dan menyelesaikan persoalan hukum warganya. ${ }^{8}$

Secara kajian yuridis tidak ada aturan - aturan pasti yang mengatur desa adat sebagai sebuah otonomi. Namun, secara kenyataan desa adat dalam penyelenggaraan pemerintahan selalu berpatokan pada otonomi aslinya. Eksistensi terhadap keberadaan desa adat, dalam konsep pengakuan dilakukan dengan de facto dan de jure. 9

Desa adat di Bali diatur dalam tiga tata sukerta, yaitu Sukerta Tata Pahryangan, Sukerta Tata Palemahan dan Sukerta Tata Pawongan. Ketiga sukerta ini berlandaskan Tri Hita Karana. Sukerta tata parhyangan merupakan otonomi desa adat dalam hal mengatur hubungan krama adat dengan Tuhan atau Pura Kahyangan desa. Kahyangan tiga yang ada di desa adat menjadi tanggungjawab desa adat itu sendiri. Dalam melaksanakan harmonisasi antara krama dengan kahyangan tiga yang diatur dalam hukum adat berupa awig-awig desa adat.

Otonomi dalam sukerta tata pawongan, mempunyai makna menjadikan sistem sosial kemasyarakatan yang harmonis antar krama di wilayah desa adat. Dalam sukerta tata pawongan mengatur prihal krama desa adat, krama tamiu dan tamiu. Ketiga jenis krama tersebut mempunyai kewajiban dan hak yang juga berbeda.

Palemahan desa adat merupakan sistem hubungan harmonis antara krama adat dengan lingkungan di wilayah atau wewidangan desa adat. Pasal 10 Perda Desa Adat

7 Anatan, L. "Coorporate Social Responsibility (Csr): Tinjauan Teoritis Dan Praktik Di Indonesia." Jurnal Manajemen Maranatha, 8(2), (2009): 66-77.

8 Dewi, A.A.I.A.A., "Eksistensi Otonomi Desa Pakraman Dalam Perspektif Plurarisme Hukum." Jurnal Magister Hukum Udayana (Udayanan Master Law Journal), (2014): 3(3)

${ }^{9}$ Marhaendra Wija Atmana, “Eksistensi Kesatuan Masyarakat Hukum Adat Dalam Politik Hukum Nasional: Pengakuan Hak-Hak Desa Pakraman dan Subak", Fakultas Hukum Udayana, 2008. 
di Bali menyebutkan bahwa palemahan desa adat terdiri dari tanah milik desa adat dan tanah guna kaya yang bersifat komunal atau individual, dimana sama-sama memiliki fungsi adat, keagamaan, tradisi, budaya dan ekonomi. Untuk tanah guna kaya tetap memperhatikan fungsi sosial hak atas tanah. Setiap orang yang berdomisili dipalemahan desa adat wajib menjaga kesucian kelestarian, kebersihan dan ketertiban.

Landasan Tri Hita Karana yang ada di ketiga sukerta desa adat, memiliki keterkaitan terhadap prinsip - prinsip pelaksanaan program CSR oleh perusahaan, yaitu prinsip keselarasan, kebersamaan, dan keseimbangan antara tujuan ekonomi, pelestarian lingkungan dan budaya, estetika dan spritual. ${ }^{10}$ Konsep pelaksanaan CSR menekankan pada unsur keharmonisan hubungan antara perusahaan dengan masyarakat, dan hubungan perusahaan dengan lingkungan. Sehingga konsep CSR memiliki kehamornisan hubungan dengan konsep THK yang dimiliki masyarakat adat di Bali.

Pasal 5 Perda Nomor 4 tahun 2019 mengatur desa adat sebagai subjek hukum dalam pemerintahan provinsi Bali. Dalam ketentuan yang mengatur tentang pendapatan lain - lain desa adat yang sah, dapat dijadikan kontruksi hukum dalam melaksanakan pungutan atau dudukan oleh desa adat. Pengaturan dilakukan melalui kesepakatan krama yang kemudian dituangkan dalam bentuk awig-awig dan pararem maupun jenis peraturan adat lainnya.

Dudukan dari krama tamiu maupun tamiu yang dilakukan oleh desa adat di atur dalam Pasal 13 Peraturan Gubernur Bali Nomor 34 Tahun 2019. Dudukan masuk dalam pendapatan lain-lain desa adat yang sah, bersamaan dengan hasil kerjasama dengan pihak ketiga di luar padruwen desa adat.

Perusahaan sebagai badan hukum dapat dikategorikan sebagai krama tamiu (manusia) ataupun pihak ketiga yang melakukan kegiatan mencari keuntungan di wewidangan desa adat. Keberadaan perusahaan dapat menjadi salah satu objek sumber pendapatan yang sah bagi desa adat. Di saat terjadinya paradok dalam pengaturan pelaksanaan program CSR pada tatanan hukum nasional, desa adat melalui prinsip budaya dan hak otonomi yang dimilikinya dapat mengelola potensi CSR untuk pemberdayaan masyarakat adatnya. Melalui bentuk kerjasama atau kesepakatan, program CSR dapat dilakukan dalam bentuk aktivitas - aktivitas serta pembuatan kebijakan yang dapat meningkatkan kompetensi krama adat diberbagai bidang. Hal ini dapat bermanfaat bagi peningkatan kualitas hidup masyarakat, yang pada akhirnya dapat menciptakan kesejahteraan masyarakat adat.

Dalam mewujudkan kesejahteraan masyarakat adat melalui program CSR perusahaan, desa adat memerlukan perangkat kaedah hukum yang baik untuk menjamin bahwa pelaksananya dapat berjalan berkelanjutan. Dalam memperhatikan sisi yuridis, sehingga banyak hal yang harus dijadikan pertimbangan dalam pembentukan suatu pengaturannya, agar penormaannya dapat diterima oleh masyarakat.

Diluar aspek yuridis, mengingat hukum tidak bebas nilai (interdisipliner) yakni hukum mempengaruhi dan dipengaruhi oleh sub sistem lain seperti budaya, sosial, politik, dan ekonomi, maka diperlukan penyelarasan kebijakan, penyusunan perencanaan strategis pelaksanaan mekanisme kerja dan pendokumentasian pelaksanaan kegiatan. Melalui sebuah kesepakatan tertulis maupun tidak tertulis, CSR

10 Tenaya, G.A.I, “Analisis Falsafah dan konsep Akutansi dalam Perspektif Filsafat Kultur Bali Tri Hita Karana dan Kesadaran Internal Lembaga terhadap Hukum Perusahaan." Malang; Tesis Program Pascasarjana Brawijaya Malang (2007). 
sebagai sebuah kewajiban hukum dari perusahaan dapat dimanfaatkan bagi kepentingan desa adat dimana perusahan tersebut berdomisili. Kesepakatan pemberian CSR dari perusahaan sebagai pendapatan kepada Desa adat dapat berlaku ketentuan - ketentuan dalam KUH Perdata.

\section{KESIMPULAN}

Putusan MK No 53/PUU-VI/2008, menggeser paradigma CSR dari yang bersifat voluntary dan Filantropi menjadi sebuah kewajiban hukum. Ini dapat menjadi celah bagi desa adat di Bali untuk menjadikan program CSR perusahaan yang ada di setiap wilayahnya menjadi sumber pendapatan yang sah. Dalam pelaksanaannya memerlukan kepastian hukum untuk menjamin keberlanjutannya. Pengaturannya dapat dilakukan dalam bentuk kesepakatan yang kemudian diatur dalam bentuk awig-awig, pararem dan jenis peraturan adat lainnya. Perolehan CSR perusahaan oleh desa adat sebagaimana ditentukan dalam Pasal 13 Pergub 34 Tahun 2019 juga dapat dilakukan melalui kesepakatan yang dituangkan dalam sebuah perjanjian pemberian CSR perusahaan kepada desa adat sebagaimana ketentuan yang berlaku dalam hukum perdata. Kesepakatan ini dapat diupayakan desa adat ketika awal pelaksanaan sosialisasi pendirian perusahaan kepada masyarakat setempat. Sehingga keabsahan dari pungutan CSR sebagai sumber pendapatan desa adat berlandaskan yuridis tidak lagi terkesan pungli. Dari kontruksi hukum yang dibentuk, sehingga dalam pengaturan CSR sebagai sumber pendapatan desa adat dapat mewujudkan kesejahteraan masyarakat.

\section{DAFTAR PUSTAKA}

\section{Buku}

Pasek Diantra I Made. Metodelogi Penelitian Hukum Normatif. (Prenada Media Group, Jakarta, 2017).

Marhaendra Wija Atmana, Eksistensi Kesatuan Masyarakat Hukum Adat Dalam Politik Hukum Nasional: Pengakuan Hak-Hak Desa Pakraman dan Subak, (Fakultas Hukum Udayana, 2008).

\section{Jurnal}

Adharinalti, A. "Eksistensi Hukum Adat Dalam Penyelenggaraan Pemerintahan Desa Di Bali." Jurnal Rechts Vinding: Media Pembinaan Hukum Nasional, 1(3), (2012): 2.

Anatan, L. “Coorporate Social Responsibility (Csr): Tinjauan Teoritis Dan Praktik Di Indonesia." Jurnal Manajemen Maranatha, 8(2), (2009): 66-77.

Dewi, A.A.I.A.A., “Eksistensi Otonomi Desa Pakraman Dalam Perspektif Plurarisme Hukum." Jurnal Magister Hukum Udayana (Udayanan Master Law Journal), (2014): 3(3)

Marhaendra Wija Atmana, "Eksistensi Kesatuan Masyarakat Hukum Adat Dalam Politik Hukum Nasional: Pengakuan Hak-Hak Desa Pakraman dan Subak", Fakultas Hukum Udayana, 2008.

Pasek Diantha I Made. "Metodelogi Penelitian Hukum Normatif." Jakarta: Prenada Media Group, (2017): 159.

Pertiwi, I. D. A. E., \& Ludigdo, U. "Implementasi Corporate Social Responsibility Berlandaskan Budaya Tri Hita Karana." Jurnal Akuntansi Multiparadigma, 4(3), (2013): 430-455. 
Tanaya, P. E. “Tinjauan Sosiologi Hukum Terhadap Corporate Social Responbility (Csr) Sebagai Etika Bisnis Dan Etika Sosial." Jurnal Komunikasi Hukum (Jkh), 2(2). Http:/ / Dx.Doi.Org/10.23887/Jkh.V2i2.8417, (2016): 270

Tanudjaja, B. B. "Perkembangan Corporate Social Responsibility Di Indonesia." Nirmana, 8(2), 92-98. Https://Doi.Org/10.9744/Nirmana.8.2.Pp.\%2092-98, (2009): 96.

Tenaya, G.A.I, “Analisis Falsafah dan konsep Akutansi dalam Perspektif Filsafat Kultur Bali Tri Hita Karana dan Kesadaran Internal Lembaga terhadap Hukum Perusahaan." Malang; Tesis Program Pascasarjana Brawijaya Malang (2007).

Yudiawan, I. D. H. "Pendapatan desa adat: Kontruksi hukum pungutan untuk Mewujudkan Bebas pungutan Liar." Jurnal magister hukum Udayana (Udayana Master Law Journal), 8(2), Https://Doi.Org/10.24843/Jmhu.2019.V08.I02.P08. (2019): 251.

\section{Peraturan Perundang- Undangan}

Undang - undang Nomor 40 Tahun 2007 tentang Perseroan Terbatas. Lembaran Negara Republik Indonesia Tahun 2007 Tahun 106

Peraturan Daerah Provinsi Bali Nomor 4 tahun 2019 tentang Desa Adat di Bali. Lembaran Daerah Provinsi Bali Tahun 2019 Nomor 4 